\title{
ANALISIS DIMENSI STRATEGI KOMPETITIF DAN PEMETAAN STRATEGIC GROUP PRODUSEN KENDARAAN SPORT UTILITY VEHICLE DI PASAR INDONESIA
}

\author{
Irfan Prarendra \\ Administrsi Bisnis, Telkom University \\ Jl. Telekomunikasi No. 1 Ters. Buahbatu - Dayeuh Kolot \\ Peggy Hariwan \\ Administrsi Bisnis, Telkom University \\ Jl. Telekomunikasi No. 1 Ters. Buahbatu - Dayeuh Kolot \\ e-mail: peggyhariwan@gmail.com
}

\begin{abstract}
The purpose of this study is to analyze the dimensions of competitive strategy and strategic mapping group of vehicle manufacturers in the segment Sport Utility Vehicle. Since the government applied liberalization automotive policy in 1999, the automotive industry in Indonesia has improved significantly so that the competition increased. It can be seen from the increasing number of foreign brands that entered Indonesia's market. National car sales continue to rise and break the number of 1.229 .903 units in 2013. The segmentation of products in the automotive industry is based on the function of vehicles consisting of passenger cars, commercial cars, buses and trucks. In the segmentation passenger car, there are four sub-segmentation are sedans, multi-purpose vehicle (MPV), sport utility vehicle (SUV) and a city car. SUV type itself is currently being developed in which the number sold in October 2013 to as many as 57.446 units. As a relatively new segment, the characteristics of competition in the SUV market has not been thoroughly established as other types of vehicles. This study uses descriptive analysis to collect data from various sources so that the results of this study will provide a comprehensive overview of the dimensions of competitive strategy and strategic group mapping vehicle manufacturers Sport Utility Vehicle (SUV) in the Indonesian market.
\end{abstract}

Keywords: Analysis of competitive strategy and dimensions stretgic groupmapping, Sport Utility Vehicle (SUV)segment 


\section{PENDAHULUAN}

\section{Latar Belakang Penelitian}

Di antara jenis kendaraan penumpang yang ada di pasar otomotif di Indonesia Sport Utility Vehicle (SUV) adalah jenis mobil penumpang yang sedang populer saat ini. Kendaraan jenis SUV ini menjadi populer karena memiliki daya angkut mendekati MPV dan kenyamanan serta kemewahan sebuah sedan. Bahkan untuk tahun 2014, pasar kendaraan SUV diprediksi akan mengalami pertumbuhan yang cukup signifikan. Terutama untuk SUV kelas menengah sekarang ini potensi pasar didominasi oleh dua pabrikan, yaitu Nissan dengan produk XTrailnya dan Honda dengan produk CR-Vnya. Sementara itu untuk pangsa pasar SUV kelas premium dikuasai oleh merek-merek Cherokee, BMW seri X3 dan X5, Lexus RX300, dan VW Toureq.

Sebenarnya, pangsa pasar SUV di tingkat dunia pun sangat besar. Persaingan ketat di pasar SUV pun terjadi. Produsen otomotif dari berbagai negara di Eropa, Jepang, AS, dan bahkan Korea berlomba membuat produk SUV. Pabrikan yang membuat SUV (Sport Utility Vehicle) saat ini adalah Acura, BMW, Cadillac, Chevrolet, Ford, Hyundai, Isuzu, Mercedes Benz, Mitsubishi, Nissan, Infiniti, Subaru, Toyota, Lexus sampai perusahaan KIA, Hyundai, dan Tata. Jeep yang dikenal sebagai legenda mobil petualang dengan Willys pun ikut bertarung dengan model Liberty dan Grand Cherokee. Bahkan perusahaan yang sepanjang sejarahnya terkenal sebagai pembuat mobil sport saat ini, Porsche, juga memproduksi SUV. Porsche saat ini memproduksi Cayenne untuk bersaing di pasar SUV.

Sejak pemerintah mengizinkan masuknya mobil impor utuh sejak tahun 1999 angka penjualan mobil SUV setiap tahunnya cukup besar. Dalam satu bulan hampir semua merek dapat menjual hingga ribuan unit. Permintaan SUV di Indonesia cenderung meningkat. Tahun 2013 total penjualan SUV sudah mencapai angka 66.179 unit. Sementara itu, menurut data penjualan SUV dari Gaikindo, hingga Juli 2014, penjualan SUV sudah menyentuh angka 32.695unit. Pada tahun 2014 ini sejumlah SUV (Sport Utility Vehicle) model baru akan memasuki pasar otomotif nasional.

Salah satu varietas produk dalam industri ini adalah Sport Utility Vehicle (SUV), yang penjualannya mencapai 6 juta di seluruh dunia dalam setahun. Di Indonesia, berdasarkan data Gaikindo, penjualannya lebih dari 5.400 unit selama 6 bulan terakhir di tahun 2014. Besarnya minat konsumen Indonesia telah menarik pabrikan untuk masuk ke pasar SUV Indonesia. Oleh karena itu, pada tahun-tahun mendatang diperkirakan semakin banyak mobil SUV yang masuk ke Indonesia.Sebagai segmen yang tergolong baru dalam dunia otomotif, karakteristik persaingan dalam pasar kendaraan SUV belum secara matang terbentuk seperti pada jenisjenis kendaraan yang lain, sehingga menjadi menarik untuk dipelajari.

\section{Rumusan Masalah Penelitian}

Dengan melihat fenomena berdasar dimensi strategi kompetitif yang relevan, maka akan sangat berguna jika kita dapat mempelajari pengelompokan yang terjadi pada produsen kendaraan SUV. 


\section{Pernyataan Tujuan}

Untuk itu, analisis dimensi strategi kompetitif dan pemetaan strategic groupakan dapat memberikan gambaran bagaimana pabrikan-pabrikan tersebut akan bertindak terhadap perubahan lingkungan bisnis di masa mendatang berdasarkan berbagai variabel strategik yang ditetapkan saat ini.

\section{LANDASAN TEORI}

Konsep analisis strategik group dikemukakan Porter (1980) di buku Competitive Strategicnya. Konsep Porter mengenai analisis strategic group ini merupakan teknik-teknik untuk menganalisis struktur di dalam suatu industri, suatu analisis yang menjembatani antara analisis struktur industri dan analisis perusahaan yang menjadi anggota dari suatu industri. Strategic group yang terbentuk dari sebuah industri tidak sama dengan segmen pasar atau strategi segmentasi melainkan berdasar pada konsepsi yang lebih luas dari postur strategi. Porter (2005) menjelaskan bahwa segmentasi pasar bersumber dari karakter instrinsik sebuah produk atau pembelinya terlepas dari strategi-strategi yang diaplikasikan oleh perusahaanperusahaan yang memproduksinya, sementara strategic groups dihasilkan dari perbedaanperbedaan strategi dari perusahaan- perusahaan di dalam industri, sehingga segmentasi sebuah industri adalah building block untuk menganalisa strategic groups

Analisis strategic group adalah suatu perangkat analisis yang didesain untuk mempelajari struktur di dalam suatu industri. Analisis strategic group dapat digunakan untuk mempelajari:

[1] Perbedaan posisi persaingan, tempat perusahaan-perusahaan pesaing berada

[2] Intensitas persaingan di dalam dan diantara kelompok-kelompok industri

[3] Potensi keuntungan dari beragam kelompok strategik di dalam industri

[4] Implikasi posisi persaingan dari perusahaan yang dianalisis

Suatu strategic group adalah suatu kelompok perusahaan di dalam suatu industri yang menerapkan strategi-strategi yang mirip atau sama pada beberapa dimensi-dimensi strategik.

Dimensi-dimensi strategik berikut biasa digunakan dalam menganalisis anggota dari sebuah industri dalam rangka mengklasifikasikan mereka di dalam beberapa strategic group:

1. 1. Spesialisasi: sejauh mana perusahaan memfokuskan usahanya pada rentang lini produk, target segmen pelanggan, dan luasnya cakupan geografis yang dilayani.

2. 2. Identitas merek: sejauh mana perusahaan mementingkan identitas mereknya dibanding berkompetisi hanya berdasar pada harga atau variabel yang lain.

3. 3. Push vs pull: sejauh mana usaha perusahaan untuk mengembangkan merek di mata pengguna produk dibanding dukungan terhadap saluran-saluran distribusi dalam menjual produknya.

4. Seleksi saluran distribusi: pemilihan saluran distribusi dari rentang antara saluran 
distribusi yang dimiliki sendiri oleh perusahaan sampai cakupan outlet yang sangat luas.

5. Kualitas produk: kualitas produk yang dihasilkan oleh perusahaan dari berbagai aspeknya.

6. Kepemimpinan teknologi: sejauh mana perusahaan berusaha menjadi pemimpin dalam kemajuan teknologi dibandingkan pengikut atau peniru teknologi.

7. Integrasi vertikal: sejauh mana pengembangan nilai tambah yang dilakukan oleh perusahaan baik integrasi secara backward maupun forward, termasuk di dalamnya apakah perusahaan memiliki saluran distribusi sendiri, memiliki retail outlet sendiri, jaringan service in-house, dan lain sebagainya.

8. Posisi biaya: sejauh mana perusahaan mengejar low-cost position pada proses manufaktur dan distribusi melalui investasi yang menunjang penurunan posisi biaya mereka.

9. Pelayanan: sejauh mana perusahaan menyertakan pelayanan dalam lini produknya, dalam bentuk engineering assistance, jaringan service in- house, kredit, dan lain sebagainya.

10. Kebijakan harga: posisi relatif harga produk perusahaan di pasar. Kebijakan harga biasanya terkait dengan variabel strategi yang lain seperti posisi biaya dan kualitas produk, akan tetapi bagaimanapun juga kebijakan harga adalah salah satu variabel strategi pembeda yang harus dilihat secaraterpisah.

11. Leverage: sejauh mana perusahaan menanggung beban financial leverage dan operating leverage.

Menurut Hunger dan Wheelen (1996), analisis strategik group dapat dilakukan dengan cara memetakan kelompok-kelompok dalam suatu industri berdasarkan persamaan dan perbedaan dimensi strategiknya yaitu dengan membagi posisi-posisi pasar para pesaing pada suatu grafik dua dimensi. Langkah pertama yang dilakukan adalah :

o Menentukan dua variable strategi atau dimensi strategi yang membedakan perusahaanperusahaan dalam satu industri, serta menggunakannya sebagai aksis vertikal dan horisontal.

o Membuat persilangan antara dua karakteristik masing-masing perusahaan.

o Membuat pengelompokkan terhadap perusahaan-perusahaan yang hampir sama satu sama lainnya dalam suau lingkaran untuk menunjukkan kelompok-kelompok strategis, dengan ukuran lingkaran berbeda-beda untuk menunjukkan andil suatu kelompok terhadap penjualan total industri.

Sementara itu, Thompson, Strickland, dan Gamble (2005) mengemukakan bahwa prosedur untuk membuat analisis strategic group yang dikembangkan oleh Porter (2005) adalah sebagai berikut :

1. Menentukan karakteristik persaingan yang membedakan perusahaan- perusahaan dalam suatu industri. Variabel yang umum digunakan dalam hal ini adalah rentang harga dan kualitas (tinggi, sedang, rendah), cakupan geografis (lokal, nasional, regional, global), 
derajat integrasi lokal (tidak ada, sebagian, seluruhnya), luas lini produk (luas dan sempit), pemilihan jalur distribusi (sejenis, banyak, semua) dan derajat penawaran jasa yang ditawarkan (nofrills, terbatas, dan pelayanan penuh).

2. Menempatkan perusahaan-perusahaan pada peta yang telah dibuat berdasarkan dua karakteristik persaingan yang telah ditentukan.

3. Menentukan perusahaan yang berada dalam satu strategic group.

4. Menggambarkan perusahaan dalam bentuk lingkaran, yang secara proporsional menunjukkan posisi market share kelompok, relatif terhadap keseluruhan industri.

Panduan praktis dari Thompson, Strickland, dan Gamble (2005) yang dijadikan acuan dalam melakukan pemetaan kelompok strategis adalah sebagai berikut :

1. Kedua variabel yang saling berpotongan (sumbu $\mathrm{X}$ dan sumbu $\mathrm{Y}$ ) tidak boleh berkorelasi erat.

2. Variabel yang dipilih untuk sumbu $X$ harus menunjukkan perbedaan yang besar bagaimana pesaing memposisikan diri mereka untuk bersaing.

3. Variabel yang digunakan untuk sumbu $\mathrm{X}$ tidak harus kuantitatif atau berkesimbungan tetapi dapat saja merupakan variabel yang berlainan atau penjelasan dari kelompok yang berbeda-beda atau bahkan kombinasi beberapa variabel.

4. Menggambarkan ukuran lingkaran proporsional terhadap gabungan penjualan perusahaan-perusahaan yang berada dalam satu kelompok strategis.

5. Jika lebih dari dua variabel kompetitif yang baik dapat digunakan untuk pemetaan, dapat dilakukan beberapa pemetaan untuk menggambarkan posisi kompetitif dalam struktur industri.

\section{METODE PENELITIAN}

Adapun metode yang digunakan di dalam penelitian ini adalah penelitian deksriptif, disertai data primer yang diperoleh dengan metoda wawancara dan data sekunder yang diperoleh dari berbagai sumber baik melalui artikel, jurnal dan internet berkaitan dengan pasar SUV. Analisis dalam penelitian ini dilakukan secara deskriptif dan analitis, untuk memperoleh gambaran yang lengkap mengenai strategi-strategi kompetitif dan pemetaan strategic group yang diterapkan perusahaan otomotif yang dapat digunakan untuk meningkatkan kinerja perusahaan. 


\section{HASIL DAN PEMBAHASAN}

Berikut ini strategi kompetitif yang relevan dengan industri yang dianalisis:

a. BMW

\begin{tabular}{|c|c|c|c|c|c|}
\hline \begin{tabular}{|l|l|} 
No & Dimensi Strategi
\end{tabular} & & & Rentang Dim & ensi & \\
\hline $\begin{array}{l}1 \text { Spesialisasi: } \\
\text { a. Segmen Pasar }\end{array}$ & & Atas & Menengah & Bawah & \\
\hline b. Luas cakupan geografis & & Nasional & $\begin{array}{l}\text { Provinsi } \\
\text { Tertentu }\end{array}$ & Kota Tertentu & \\
\hline 2 | Identitas Merek & Kemewahan & Kenyamanan & Kehandalan & Keekonomisan & \\
\hline 3 Pilihan Saluran Distribusi & Milik sendiri & $\begin{array}{l}\text { Berbagi } \\
\text { Kepemilikan }\end{array}$ & $\begin{array}{l}\text { Independen } \\
\text { Eksklusif }\end{array}$ & $\begin{array}{l}\text { Independen } \\
\text { Non-Eksklusif }\end{array}$ & \\
\hline \begin{tabular}{|l|l|}
4 & Kualitas Produk \\
\end{tabular} & & Sangat Baik & Baik & Standar & \\
\hline \begin{tabular}{|l|l|l} 
Kepemimpinan Teknologi & \\
\end{tabular} & & Pemimpin & Tertentu & Minim & \\
\hline \begin{tabular}{l|l}
6 & Posisi Biaya \\
\end{tabular} & CBU IU & CBU ATPM & CKD & $\begin{array}{l}\text { Diproduksi di } \\
\text { Indonesia }\end{array}$ & \\
\hline 7) Pelayanan & Warranty & \begin{tabular}{|l|} 
Service \\
Inclusive \\
\end{tabular} & $\begin{array}{l}\begin{array}{l}\text { Financial } \\
\text { Service }\end{array} \\
\end{array}$ & \begin{tabular}{|l|} 
Roadside \\
Assistance
\end{tabular} & $\begin{array}{l}\text { Buy-back } \\
\text { guarante }\end{array}$ \\
\hline \begin{tabular}{|l|l|} 
Kebijakan Harga \\
\end{tabular} & & $>350$ juta & $250-350$ juta & $150-250$ juta & \\
\hline \begin{tabular}{|l|l}
9 & $\begin{array}{l}\text { Evolusi Produk: } \\
\text { a. Minor }\end{array}$ \\
\end{tabular} & 1 Tahun & 2 Tahun & 3 tahun & 4 Tahun & 5 Tahun \\
\hline b. Mayor & 1 Tahun & 2Tahun & 3 tahun & 4Tahun & 5 Tahun \\
\hline
\end{tabular}

b. Lexus

\begin{tabular}{|c|c|c|c|c|c|}
\hline \begin{tabular}{|l|l|} 
No & Dimensi Strategi \\
\end{tabular} & & & Rentang Dim & ensi & \\
\hline $\begin{array}{l}1 \text { Spesialisasi: } \\
\text { a. Segmen Pasar }\end{array}$ & & Atas & Menengah & Bawah & \\
\hline b. Luas cakupan geografis & & Nasional & \begin{tabular}{|l|} 
Provinsi \\
Tertentu \\
\end{tabular} & Kota Tertentu & \\
\hline 2 Identitas Merek & Kemewahan & Kenyamanan & Kehandalan & Keekonomisan & \\
\hline 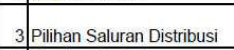 & Milik sendiri & $\begin{array}{l}\text { Berbagi } \\
\text { Kepemilikan }\end{array}$ & \begin{tabular}{|l|} 
Independen \\
Eksklusif
\end{tabular} & \begin{tabular}{|l|} 
Independen \\
Non-Eksklusif \\
\end{tabular} & \\
\hline \begin{tabular}{|l|l|} 
Kualitas Produk \\
\end{tabular} & & Sangat Baik & Baik & Standar & \\
\hline 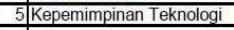 & & Pemimpin & Tertentu & Minim & \\
\hline \begin{tabular}{l|l}
6 & Posisi Biaya \\
\end{tabular} & CBU IU & CBU ATPM & CKD & \begin{tabular}{|l}
$\begin{array}{l}\text { Diproduksi di } \\
\text { Indonesia }\end{array}$ \\
\end{tabular} & \\
\hline 7) Pelayanan & Warranty & $\begin{array}{l}\text { Service } \\
\text { Inclusive }\end{array}$ & $\begin{array}{l}\text { Financial } \\
\text { Service }\end{array}$ & \begin{tabular}{|l} 
Roadside \\
Assistance
\end{tabular} & $\begin{array}{l}\text { Buy-back } \\
\text { guarantee }\end{array}$ \\
\hline \begin{tabular}{|l|l|} 
K Kebjiakan Harga \\
\end{tabular} & & $>350$ juta & $250-350$ juta & $150-250$ juta & \\
\hline $\begin{array}{l}9 \text { Evolusi Produk: } \\
\text { a. Minor } \\
\text { b. Mayor }\end{array}$ & 1 Tahun & 2 Tahun & $\frac{3 \text { tahun }}{3 \text { tahun }}$ & $\frac{4 \text { Tahun }}{4 \text { Tahun }}$ & 5 Tahun \\
\hline b. Mayor & 1 Tahun & 2Tahun & 3 tahun & 4 Tahun & 5 Tahun \\
\hline
\end{tabular}

c. Mercedes

\begin{tabular}{|c|c|c|c|c|c|}
\hline \begin{tabular}{|l|l|} 
No Dimensi Strategi \\
\end{tabular} & & & Rentang Dim & ensi & \\
\hline 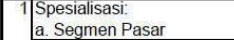 & & Atas & Menengah & Bawah & \\
\hline b. Luas cakupan geografis & & Nasional & $\begin{array}{l}\text { Provinsi } \\
\text { Tertentu }\end{array}$ & Kota Tertentu & \\
\hline 2 Identitas Merek & Kemewahan & Kenyamanan & Kehandalan & Keekonomisan & \\
\hline 3 Pilihan Saluran Distribusi & Milik sendin & \begin{tabular}{|l} 
Berbagi \\
Kepemilikan
\end{tabular} & \begin{tabular}{|l|} 
Independen \\
Eksklusif
\end{tabular} & $\begin{array}{l}\text { Independen } \\
\text { Non-Fksklusif }\end{array}$ & \\
\hline 4 Kualitas Produk & & Sangat Baik & Baik & Standar & \\
\hline 5 Kepemimpinan Teknologi & & Pemimpin & Tertentu & Minim & \\
\hline \begin{tabular}{l|l}
6 & Posisi Biaya
\end{tabular} & CBU IU & CBU ATPM & CKD & $\begin{array}{l}\begin{array}{l}\text { Diproduksi di } \\
\text { Indonesia }\end{array} \\
\end{array}$ & \\
\hline 7 Pelayanan & Warranty & $\begin{array}{l}\text { Service } \\
\text { Inclusive }\end{array}$ & $\begin{array}{l}\text { Financial } \\
\text { Service }\end{array}$ & \begin{tabular}{|l} 
Roadside \\
Assistance
\end{tabular} & $\begin{array}{l}\text { Buy-back } \\
\text { guarantee }\end{array}$ \\
\hline Kebijakan Harga & & $>350$ juta & $250-350$ juta & $150-250$ juta & \\
\hline \begin{tabular}{l|l}
9 & Evolusi Produk: \\
a. Minor
\end{tabular} & 1 Tahun & 2 Tahun & 3 tahun & 4 Tahun & 5 Tahun \\
\hline b. Mayor & 1 Tahun & 2Tahun & 3 tahun & $\frac{4}{4}$ Tahun & 5 Tahun \\
\hline
\end{tabular}




\section{d. Daimler-Chrysler}

\begin{tabular}{|c|c|c|c|c|c|}
\hline \begin{tabular}{|l|l} 
No & Dimensi Strategi \\
\end{tabular} & \multicolumn{5}{|c|}{ Rentang Dimensi } \\
\hline 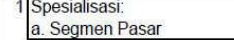 & & |Atas & Menengah & Bawah & \\
\hline b. Luas cakupan geografis & & Nasional & \begin{tabular}{|l} 
Provinsi \\
Tertentu
\end{tabular} & Kota Tertentu & \\
\hline 2 Identitas Merek & Kemewahan & Kenyamanan & Kehandalan & Keekonomisan & \\
\hline 3 Pilihan Saluran Distribusi & Milik sendiri & $\begin{array}{l}\text { Berbagi } \\
\text { Kepemilikan }\end{array}$ & $\begin{array}{l}\text { Independen } \\
\text { Eksklusif }\end{array}$ & \begin{tabular}{|l|} 
Independen \\
Non-Eksklusif
\end{tabular} & \\
\hline \begin{tabular}{l|l} 
Kualitas Produk \\
\end{tabular} & & Sangat Baik & Baik & Standar & \\
\hline \begin{tabular}{|l|l|l} 
Kepemimpinan Teknologi \\
\end{tabular} & & Pemimpin & Tertentu & Minim & \\
\hline $\begin{array}{ll}6 & \text { Posisi Biaya } \\
\end{array}$ & CBU IU & CBU ATPM & CKD & $\begin{array}{l}\text { Diproduksi di } \\
\text { Indonesia }\end{array}$ & \\
\hline 7 Pelayanan & Warranty & $\begin{array}{l}\begin{array}{l}\text { Service } \\
\text { Inclusive }\end{array} \\
\end{array}$ & $\begin{array}{l}\text { Financial } \\
\text { Service }\end{array}$ & \begin{tabular}{|l|} 
Roadside \\
Assistance \\
\end{tabular} & $\begin{array}{l}\text { Buy-back } \\
\text { guarantee }\end{array}$ \\
\hline \begin{tabular}{|l|l|} 
Kebjiakan Harga \\
\end{tabular} & & $>350$ juta & 250-350 juta & 150-250 juta & \\
\hline \begin{tabular}{l|l|}
9 & Evolusi Produk: \\
a. Minor
\end{tabular} & 1 Tahun & 2 Tahun & 3 tahun & 4 Tahun & 5 Tahun \\
\hline b. Mayor & 1 Tahun & 2Tahun & 3 tahun & 4 Tahun & 5 Tahun \\
\hline
\end{tabular}

\section{e. Land Rover}

\begin{tabular}{|c|c|c|c|c|c|}
\hline No Dimensi Strategi & & & Rentang Dim & iensi & \\
\hline $1\left\{\begin{array}{l}\text { Spesialisasi: } \\
\text { a. Segmen Pasar }\end{array}\right.$ & & Atas & Menengah & Bawah & \\
\hline b. Luas cakupan geografis & & Nasional & \begin{tabular}{|l} 
Provinsi \\
Tertentu
\end{tabular} & Kota Tertentu & \\
\hline 2 Identitas Merek & Kemewahan & Kenyamanan & Kehandalan & Keekonomisan & \\
\hline 3 Pilihan Saluran Distribusi & Milik sendiri & \begin{tabular}{|l|} 
Berbagi \\
Kepemilikan
\end{tabular} & $\begin{array}{l}\text { Independen } \\
\text { Eksklusif }\end{array}$ & \begin{tabular}{|l} 
Independen \\
Non-Eksklusif
\end{tabular} & \\
\hline \begin{tabular}{l|l}
4 & Kualitas Produk \\
\end{tabular} & & Sangat Baik & Baik & Standar & \\
\hline \begin{tabular}{c|c|}
5 & Kepemimpinan Teknologi \\
\end{tabular} & & Pemimpin & Tertentu & Minim & \\
\hline \begin{tabular}{l|l}
6 & Posisi Biaya \\
\end{tabular} & CBUIU & CBU ATPM & CKD & $\begin{array}{l}\text { Diproduksi di } \\
\text { Indonesia }\end{array}$ & \\
\hline 7 Pelayanan & Warranty & \begin{tabular}{|l} 
Service \\
Inclusive \\
\end{tabular} & \begin{tabular}{|l}
$\begin{array}{l}\text { Financial } \\
\text { Service }\end{array}$ \\
\end{tabular} & $\begin{array}{l}\text { Roadside } \\
\text { Assistance }\end{array}$ & $\begin{array}{l}\text { Buy-back } \\
\text { guarantee }\end{array}$ \\
\hline 8 Kebijakan Harga & & $>350$ juta & $250-350$ juta & $150-250$ juta & \\
\hline \begin{tabular}{l|l}
9 & Evolusi Produk: \\
a. Minor
\end{tabular} & 1 Tahun & 2 Tahun & 3 tahun & 4 Tahun & 5 Tahun \\
\hline b. Mayor & 1 Tahun & 2 Tahun & 3 tahun & 4 Tahun & 5 Tahun \\
\hline
\end{tabular}

\section{f. Honda}

\begin{tabular}{|c|c|c|c|c|c|}
\hline No Dimensi Strategi & & & Rentang Dim & ensi & \\
\hline $\begin{array}{l}1 \text { Spesialisasi: } \\
\text { a. Segmen Pasar }\end{array}$ & & Atas & Menengah & Bawah & \\
\hline b. Luas cakupan geografis & & Nasional & \begin{tabular}{|l} 
Provinsi \\
Tertentu \\
\end{tabular} & Kota Tertentu & \\
\hline 2 Identitas Merek & Kemewahan & Kenyamanan & Kehandalan & Keekonomisan & \\
\hline 3 Pilihan Saluran Distribusi & Milik sendiri & \begin{tabular}{|l|} 
Berbagi \\
Kepemilikan
\end{tabular} & $\begin{array}{l}\text { Independen } \\
\text { Eksklusif }\end{array}$ & \begin{tabular}{|l|} 
Independen \\
Non-Eksklusif
\end{tabular} & \\
\hline $4 /$ Kualitas Produk & & Sangat Baik & Baik & Standar & \\
\hline 5 Kepemimpinan Teknologi & & Pemimpin & Tertentu & Minim & \\
\hline \begin{tabular}{l|l}
6 & Posisi Biaya \\
\end{tabular} & CBUIU & CBU ATPM & CKD & $\begin{array}{l}\text { Diproduksi di } \\
\text { Indonesia }\end{array}$ & \\
\hline 7 Pelayanan & Warranty & $\begin{array}{l}\text { Service } \\
\text { Inclusive }\end{array}$ & $\begin{array}{l}\text { Financial } \\
\text { Service }\end{array}$ & \begin{tabular}{|l|} 
Roadside \\
Assistance
\end{tabular} & $\begin{array}{l}\text { Buy-back } \\
\text { guarantee }\end{array}$ \\
\hline \begin{tabular}{l|l} 
Kebijakan Harga \\
\end{tabular} & & $>350$ juta & $250-350$ juta & $150-250$ juta & \\
\hline $9 \begin{array}{l}\text { Evolusi Produk: } \\
\text { a. Minor }\end{array}$ & 1 Tahun & 2 Tahun & 3 tahun & 4 Tahun & 5 Tahun \\
\hline b. Mayor & 1 Tahun & 2 Tahun & 3 tahun & 4 Tahun & 5 Tahun \\
\hline
\end{tabular}




\section{g. Suzuki}

\begin{tabular}{|c|c|c|c|c|c|}
\hline \begin{tabular}{l|l} 
No & Dimensi Strategi
\end{tabular} & & & Rentang Dim & ensi & \\
\hline 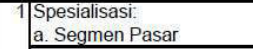 & & Atas & Menengah & Bawah & \\
\hline b. Luas cakupan geografis & & Nasional & \begin{tabular}{|l} 
Provinsi \\
Tertentu
\end{tabular} & Kota Tertentu & \\
\hline 2 Identitas Merek & Kemewahan & Kenyamanan & Kehandalan & Keekonomisan & \\
\hline 3 Pilihan Saluran Distribusi & Milik sendiri & $\begin{array}{l}\text { Berbagi } \\
\text { Kepemilikan }\end{array}$ & $\begin{array}{l}\text { Independen } \\
\text { Eksklusif }\end{array}$ & $\begin{array}{l}\text { Independen } \\
\text { Non-Eksklusif }\end{array}$ & \\
\hline \begin{tabular}{l|l} 
Kualitas Produk \\
\end{tabular} & & Sangat Baik & Baik & Standar & \\
\hline 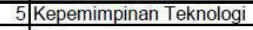 & & Pemimpin & Tertentu & Minim & \\
\hline \begin{tabular}{l|l}
6 & Posisi Biaya \\
\end{tabular} & CBU IU & CBU ATPM & CKD & $\begin{array}{l}\text { Diproduksi di } \\
\text { Indonesia }\end{array}$ & \\
\hline 7 Pelayanan & Warranty & \begin{tabular}{|l|l|} 
Service \\
Inclusive
\end{tabular} & \begin{tabular}{|l}
$\begin{array}{l}\text { Financial } \\
\text { Service }\end{array}$ \\
\end{tabular} & \begin{tabular}{|l|} 
Roadside \\
Assistance
\end{tabular} & $\begin{array}{l}\text { Buy-back } \\
\text { guarantee }\end{array}$ \\
\hline 8 Kebjiakan Harga & & $>350$ juta & $250-350$ juta & $150-250$ juta & \\
\hline \begin{tabular}{l|l}
9 & Evolusi Produk: \\
a. Minor
\end{tabular} & 1 Tahun & 2 Tahun & 3 tahun & 4 Tahun & 5 Tahun \\
\hline b. Mayor & 1 Tahun & 2 Tahun & 3 tahun & 4 Tahun & $\begin{array}{l}5 \text { lanun } \\
\text { atau lebih }\end{array}$ \\
\hline
\end{tabular}

h. Nissan

\begin{tabular}{|c|c|c|c|c|c|}
\hline No Dimensi Strategi & & & Rentang Dim & ensi & \\
\hline 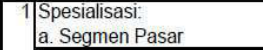 & & Atas & Menengah & Bawah & \\
\hline b. Luas cakupan geografis & & Nasional & \begin{tabular}{|l} 
Provinsi \\
Tertentu \\
\end{tabular} & Kota Tertentu & \\
\hline 2 Identitas Merek & Kemewahan & Kenyamanan & Kehandalan & Keekonomisan & \\
\hline 3 Pilihan Saluran Distribusi & Milik sendiri & \begin{tabular}{|l} 
Berbagi \\
Kepemilikan
\end{tabular} & $\begin{array}{l}\text { Independen } \\
\text { Eksklusif }\end{array}$ & \begin{tabular}{|l|} 
Independen \\
Non-Eksklusif
\end{tabular} & \\
\hline \begin{tabular}{l|l}
4 & Kualitas Produk \\
\end{tabular} & & Sangat Baik & Baik & Standar & \\
\hline 5 Kepemimpinan Teknologi & & Pemimpin & Tertentu & Minim & \\
\hline \begin{tabular}{l|l}
6 & Posisi Biaya \\
\end{tabular} & CBUIU & CBU ATPM & CKD & $\begin{array}{l}\text { Diproduksi di } \\
\text { Indonesia }\end{array}$ & \\
\hline 7) Pelayanan & Warranty & $\begin{array}{l}\text { Service } \\
\text { Inclusive }\end{array}$ & \begin{tabular}{|l} 
Financial \\
Service
\end{tabular} & \begin{tabular}{|l} 
Roadside \\
Assistance
\end{tabular} & $\begin{array}{l}\text { Buy-back } \\
\text { guarantee }\end{array}$ \\
\hline 8 Kebijakan Harga & & $>350$ juta & $250-350$ juta & $150-250$ juta & \\
\hline $\begin{array}{l}9 \text { Evolusi Produk: } \\
\text { a. Minor }\end{array}$ & 1 Tahun & 2 Tahun & 3 tahun & 4 Tahun & 5 Tahun \\
\hline b. Mayor & 1 Tahun & 2 Tahun & 3 tahun & 4 Tahun & 5 Tahun \\
\hline
\end{tabular}

i. Toyota

\begin{tabular}{|c|c|c|c|c|c|}
\hline \begin{tabular}{l|l} 
No & Dimensi Strategi
\end{tabular} & \multicolumn{5}{|c|}{ Rentang Dimensi } \\
\hline 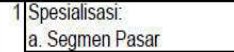 & & Atas & Menengah & Bawah & \\
\hline b. Luas cakupan geografis & & Nasional & $\begin{array}{l}\text { Provinsi } \\
\text { Tertentu }\end{array}$ & Kota Tertentu & \\
\hline 2 Identitas Merek & Kemewahan & Kenyamanan & Kehandalan & Keekonomisan & \\
\hline 3 Pilihan Saluran Distribusi & Milik sendiri & \begin{tabular}{|l} 
Berbagi \\
Kepemilikan
\end{tabular} & \begin{tabular}{|l|} 
Independen \\
Eksklusif
\end{tabular} & \begin{tabular}{|l|} 
Independen \\
Non-Eksklusif
\end{tabular} & \\
\hline \begin{tabular}{l|l}
4 & Kualitas Produk
\end{tabular} & & Sangat Baik & Baik & Standar & \\
\hline \begin{tabular}{c|c|c|} 
Kepemimpinan Teknologi
\end{tabular} & & Pemimpin & Tertentu & Minim & \\
\hline 6 Posisi Biaya & CBUIU & CBU ATPM & CKD & $\begin{array}{l}\text { Diproduksi di } \\
\text { Indonesia }\end{array}$ & \\
\hline $7 \mid$ Pelayanan & Warranty & \begin{tabular}{|l|} 
Service \\
Inclusive
\end{tabular} & \begin{tabular}{|l} 
Financial \\
Service
\end{tabular} & \begin{tabular}{|l} 
Roadside \\
Assistance
\end{tabular} & $\begin{array}{l}\text { Buy-back } \\
\text { guarantee }\end{array}$ \\
\hline \begin{tabular}{l|l|}
8 Kebijakan Harga \\
\end{tabular} & & $>350$ juta & 250-350 juta & 150-250 juta & \\
\hline \begin{tabular}{l|l}
9 & Evolusi Produk: \\
a. Minor
\end{tabular} & 1 Tahun & 2 Tahun & 3 tahun & 4 Tahun & 5 Tahun \\
\hline b. Mayor & 1 Tahun & 2 Tahun & 3 tahun & 4 Tahun & 5 Tahun \\
\hline
\end{tabular}




\section{j. Mazda}

\begin{tabular}{|c|c|c|c|c|c|}
\hline \begin{tabular}{l|l} 
No & Dimensi Strategi
\end{tabular} & & & Rentang Dime & ensi & \\
\hline 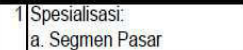 & & Atas & Menengah & Bawah & \\
\hline b. Luas cakupan geografis & & Nasional & \begin{tabular}{|l} 
Provinsi \\
Tertentu
\end{tabular} & Kota Tertentu & \\
\hline 2 Identitas Merek & Kemewahan & Kenyamanan & Kehandalan & Keekonomisan & \\
\hline 3 Pilihan Saluran Distribusi & Milik sendiri & \begin{tabular}{|l} 
Berbagi \\
Kepemilikan
\end{tabular} & \begin{tabular}{|l|} 
Independen \\
Eksklusif
\end{tabular} & $\begin{array}{l}\text { Independen } \\
\text { Non-Eksklusif } \\
\end{array}$ & \\
\hline \begin{tabular}{l|l|}
4 Kualitas Produk \\
\end{tabular} & & Sangat Baik & Baik & Standar & \\
\hline 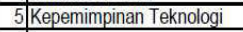 & & Pemimpin & Tertentu & Minim & \\
\hline 6 Posisi Biaya & CBU IU & CBU ATPM & CKD & $\begin{array}{l}\text { Diproduksi di } \\
\text { Indonesia }\end{array}$ & \\
\hline 7) Pelayanan & Warranty & \begin{tabular}{|l|} 
Service \\
Inclusive
\end{tabular} & \begin{tabular}{|l|} 
Financial \\
Service
\end{tabular} & $\begin{array}{l}\text { Roadside } \\
\text { Assistance }\end{array}$ & $\begin{array}{l}\text { Buy-back } \\
\text { guarantee }\end{array}$ \\
\hline 8 Kebijakan Harga & & $>350$ juta & $250-350$ juta & $150-250$ juta & \\
\hline $9 \begin{array}{l}\text { Evolusi Produk: } \\
\text { a. Minor }\end{array}$ & 1 Tahun & 2 Tahun & 3 tahun & 4 Tahun & 5 Tahun \\
\hline b. Mayor & 1 Tahun & 2 Tahun & 3 tahun & 4 Tahun & 5 Tahun \\
\hline
\end{tabular}

k. Ford

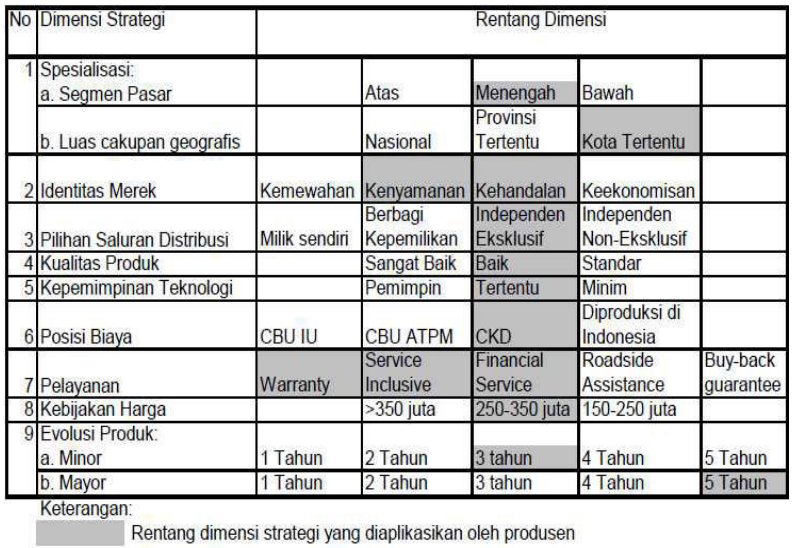

1. Chevrolet

\begin{tabular}{|c|c|c|c|c|c|}
\hline No Dimensi Strategi & & & Rentang Dim & iensi & \\
\hline $1 \begin{array}{l}\text { Spesialisasi: } \\
\text { a. Segmen Pasar }\end{array}$ & & Atas & Menengah & Bawah & \\
\hline b. Luas cakupan geografis & & Nasional & \begin{tabular}{|l} 
Provinsi \\
Tertentu
\end{tabular} & Kota Tertentu & \\
\hline 2 Identitas Merek & Kemewahan & Kenyamanan & Kehandalan & Keekonomisan & \\
\hline 3 Pilihan Saluran Distribusi & Milik sendiri & \begin{tabular}{|l|} 
Berbagi \\
Kepemilikan
\end{tabular} & $\begin{array}{l}\text { Independen } \\
\text { Eksklusif }\end{array}$ & $\begin{array}{l}\mid \text { Independen } \\
\text { Non-Eksklusif }\end{array}$ & \\
\hline \begin{tabular}{l|l}
4 & Kualitas Produk \\
\end{tabular} & & Sangat Baik & Baik & Standar & \\
\hline \begin{tabular}{c|c|} 
Kepemimpinan Teknologi \\
\end{tabular} & & Pemimpin & Tertentu & Minim & \\
\hline \begin{tabular}{l|l}
6 & Posisi Biaya \\
\end{tabular} & CBUIU & CBU ATPM & CKD & $\begin{array}{l}\text { Diproduksi di } \\
\text { Indonesia }\end{array}$ & \\
\hline 7) Pelayanan & Warranty & $\begin{array}{l}\text { Service } \\
\text { Inclusive }\end{array}$ & $\begin{array}{l}\text { Financial } \\
\text { Service }\end{array}$ & $\begin{array}{l}\text { Roadside } \\
\text { Assistance }\end{array}$ & $\begin{array}{l}\text { Buy-back } \\
\text { guarantee }\end{array}$ \\
\hline \begin{tabular}{l|l} 
Kebijakan Harga \\
\end{tabular} & & $>350$ juta & $250-350$ juta & $150-250$ juta & \\
\hline \begin{tabular}{l|l}
9 & $\begin{array}{l}\text { Evolusi Produk: } \\
\text { a. Minor }\end{array}$
\end{tabular} & 1 Tahun & 2 Tahun & 3 tahun & 4 Tahun & 5 Tahun \\
\hline b. Mayor & 1 Tahun & 2 Tahun & 3 tahun & 4 Tahun & 5 Tahun \\
\hline
\end{tabular}


m. Daihatsu

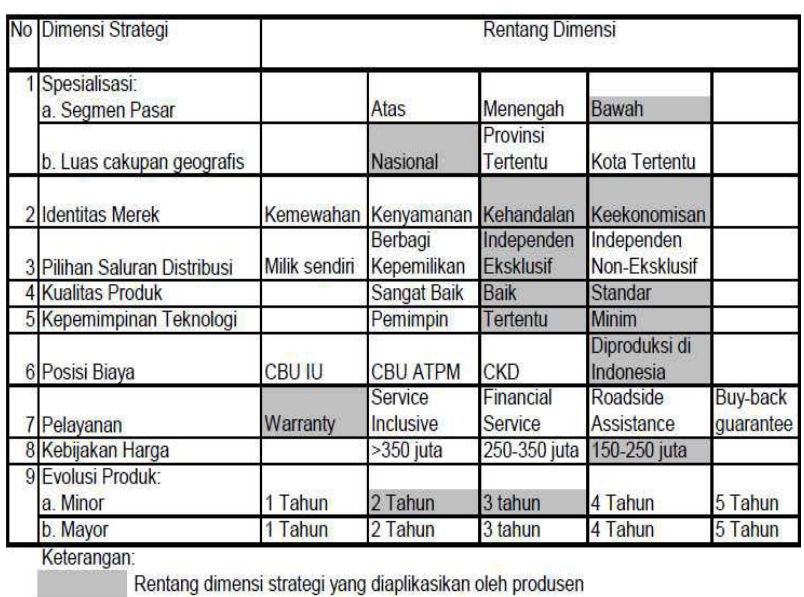

n. KIA

\begin{tabular}{|c|c|c|c|c|c|}
\hline No Dimensi Strategi & & & Rentang Dime & ensi & \\
\hline $\begin{array}{l}1 \text { Spesialisasi: } \\
\text { a. Segmen Pasar }\end{array}$ & & Atas & Menengah & Bawah & \\
\hline b. Luas cakupan geografis & & Nasional & \begin{tabular}{|l} 
Provinsi \\
Tertentu
\end{tabular} & Kota Tertentu & \\
\hline 2 Identitas Merek & Kemewahan & Kenyamanan & Kehandalan & Keekonomisan & \\
\hline 3 Pilihan Saluran Distribusi & Milik sendiri & \begin{tabular}{|l|} 
Berbagi \\
Kepemilikan
\end{tabular} & \begin{tabular}{|l|} 
Independen \\
Eksklusif
\end{tabular} & \begin{tabular}{|l|} 
Independen \\
Non-Eksklusif
\end{tabular} & \\
\hline $4 /$ Kualitas Produk & & Sangat Baik & Baik & Standar & \\
\hline 5 Kepemimpinan Teknologi & & Pemimpin & Tertentu & Minim & \\
\hline \begin{tabular}{l|l}
6 & Posisi Biaya
\end{tabular} & CBU IU & CBU ATPM & CKD & $\begin{array}{l}\text { Diproduksi di } \\
\text { Indonesia }\end{array}$ & \\
\hline 7) Pelayanan & Warranty & $\begin{array}{l}\text { Service } \\
\text { Inclusive }\end{array}$ & \begin{tabular}{|l} 
Financial \\
Service
\end{tabular} & \begin{tabular}{|l} 
Roadside \\
Assistance
\end{tabular} & \begin{tabular}{|l|} 
Buy-back \\
guarantee
\end{tabular} \\
\hline \begin{tabular}{l|l} 
Kebijakan Harga \\
\end{tabular} & & $>350$ juta & 250-350 juta & $150-250$ juta & \\
\hline $\begin{array}{l}9 \text { Evolusi Produk: } \\
\text { a. Minor }\end{array}$ & 1 Tahun & 2Tahun & 3 tahun & 4 Tahun & 5 Tahun \\
\hline b. Mayor & 1 Tahun & 2 Tahun & 3 tahun & 4 Tahun & 5 Tahun \\
\hline
\end{tabular}

o. Hyundai

\begin{tabular}{|c|c|c|c|c|c|}
\hline \begin{tabular}{|l|l} 
No & Dimensi Strategi \\
\end{tabular} & & & Rentang Dim & & \\
\hline $1 \mid \begin{array}{l}\text { Spesialisasi: } \\
\text { a. Segmen Pasar }\end{array}$ & & Atas & Menengah & Bawah & \\
\hline b. Luas cakupan geografis & & Nasional & \begin{tabular}{|l} 
Provinsi \\
Tertentu
\end{tabular} & Kota Tertentu & \\
\hline 2 Identitas Merek & Kemewahan & Kenyamanan & Kehandalan & Keekonomisan & \\
\hline 3 Pilihan Saluran Distribusi & Milik sendiri & \begin{tabular}{|l|} 
Berbagi \\
Kepemilikan
\end{tabular} & \begin{tabular}{|l} 
Independen \\
Eksklusif
\end{tabular} & $\begin{array}{l}\text { Independen } \\
\text { Non-Eksklusif }\end{array}$ & \\
\hline $4 \sqrt{\text { Kualitas Produk }}$ & & Sangat Baik & Baik & Standar & \\
\hline 5 Kepemimpinan Teknologi & & Pemimpin & Tertentu & Minim & \\
\hline 6) Posisi Biaya & |CBUIU & CBU ATPM & CKD & $\begin{array}{l}\text { Diproduksi di } \\
\text { Indonesia }\end{array}$ & \\
\hline 7 Pelayanan & Warranty & $\begin{array}{l}\begin{array}{l}\text { Service } \\
\text { Inclusive }\end{array} \\
\end{array}$ & \begin{tabular}{|l|}
$\begin{array}{l}\text { Financial } \\
\text { Service }\end{array}$ \\
\end{tabular} & $\begin{array}{l}\text { Roadside } \\
\text { Assistance }\end{array}$ & $\begin{array}{l}\text { Buy-back } \\
\text { guarantee }\end{array}$ \\
\hline \begin{tabular}{l|l}
8 Kebijakan Harga \\
\end{tabular} & & $>350$ juta & $250-350$ juta & $150-250$ juta & \\
\hline 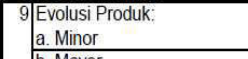 & 1 Tahun & 2 Tahun & 3 tahun & 4 Tahun & 5 Tahun \\
\hline b. Mayor & 1 Tahun & 2 Tahun & 3 tahun & 4 Tahun & 5 Tahun \\
\hline
\end{tabular}

Atas dasar hasil analisis terhadap pilihan dimensi-dimensi strategi kompetitif pada produsen kendaraan SUV di atas, analisis pemetaan produsen SUV dalam peta strategic group terhadap dimensi-dimensi strategi kompetitif yang dipilih tersebut sehingga kemiripan pilihan-pilihan yang diambil antar produsen dapat lebih mudah dipahami dalam kerangka industrii secara 
keseluruhan.

a. Peta strategic group spesialisasi segmen vs pilihan saluran distribusi

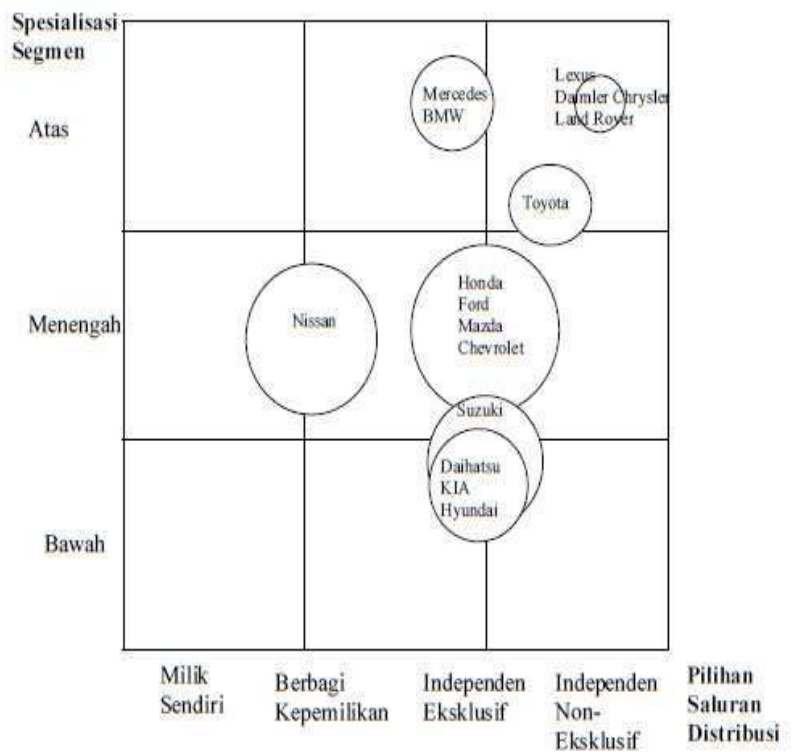

b. Peta strategic group luas cakupan geografis vs indentitas merek

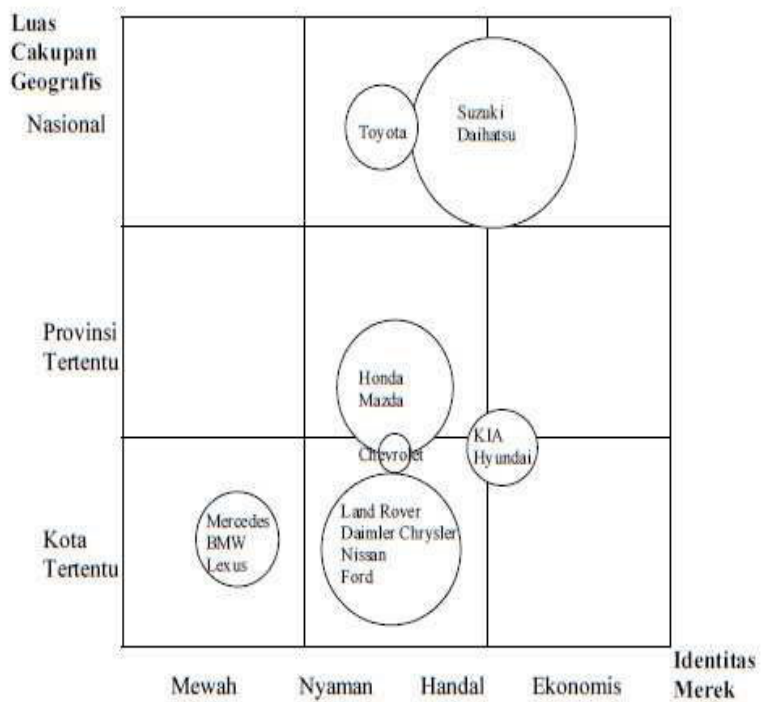


c. Peta strategic group posisi biaya vs pelayaan

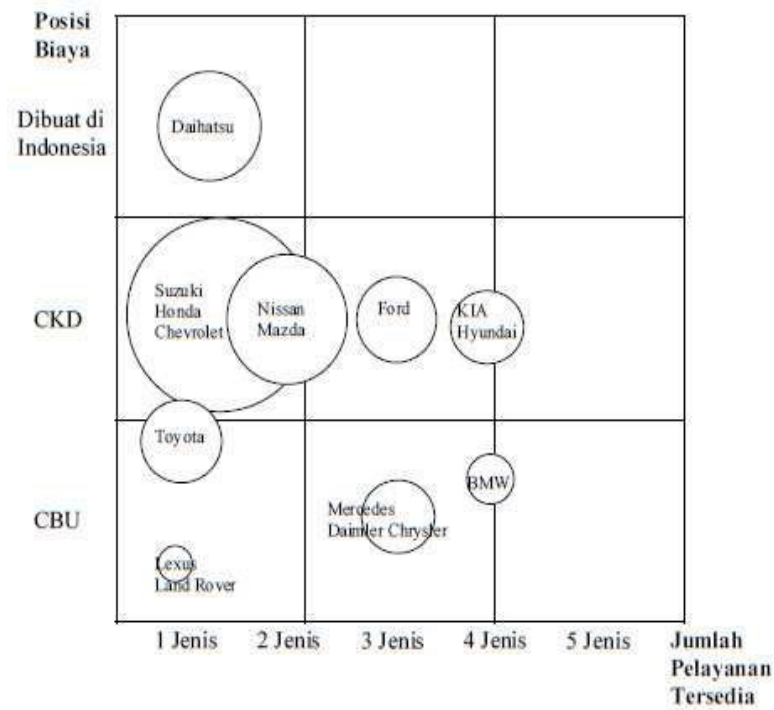

d. Peta stretegik group kualitas produk vs evolusi produk

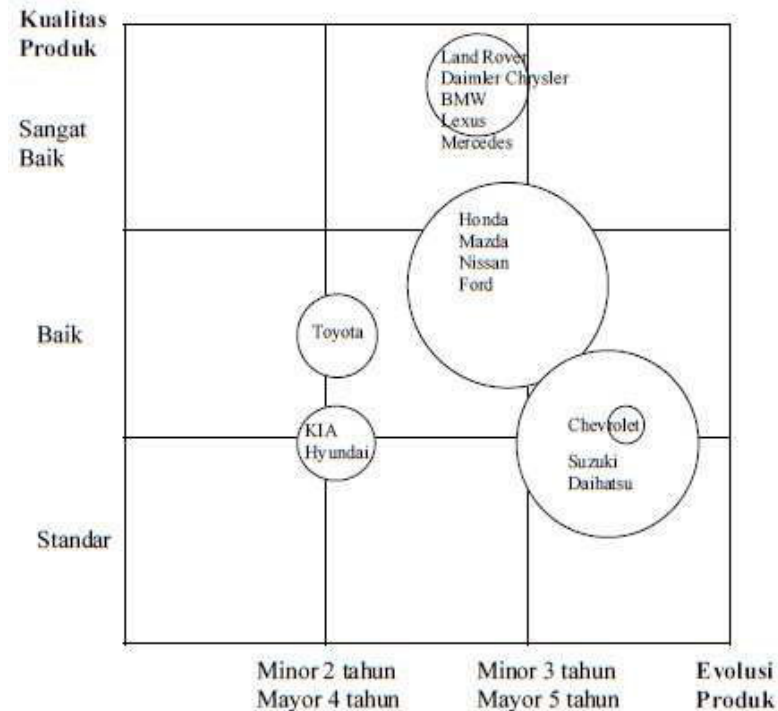


e. Peta strategic group harga vs kepemimpinan teknologi

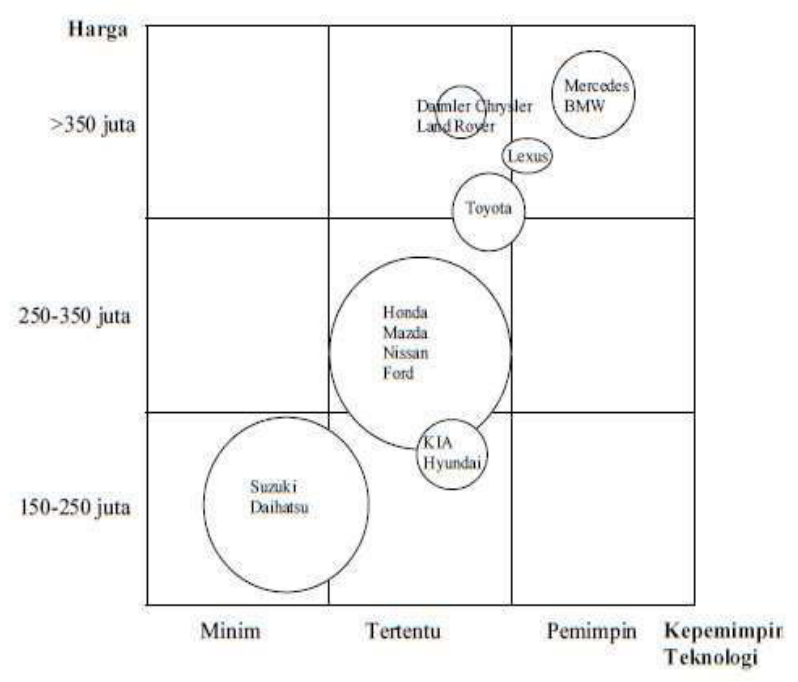

f. Peta strategic group and intergroup rivalry

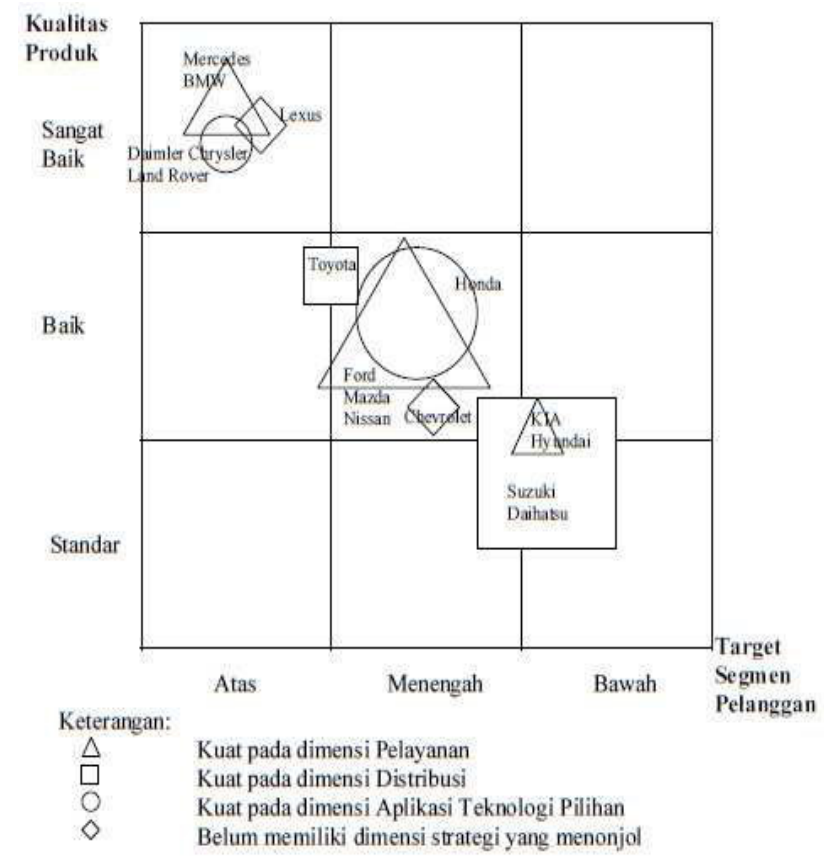

\section{Analisis Mobility Barriers}

Hambatan pergerakan antar group adalah faktor yang menghambar pergerakan sebuah perusahaan dari satu posisi strategic menuju posisi strategic yang lain. Berikut ini hambatan pergerakan yang ada pada masing-masing group sesuai target segmen pelanggan mereka saat ini:

a. Produsen SUVdengan target segmen konsumen kelas atas lebih mengandalkan pada brand image dan kualitas kenyamanan dan kemewahan produk. BMW, Mecedez Benz adalah pabrikan yang telah lama mendapat image sebagai penghasil produk otomotif kelas 
premium. Mercedes dan BMW selama puluhan tahun menghadirkan hambatan tambahan bagi strategic group yang lain untuk menghadirkan pelayanan yang memuaskan hampir di semua kota-kota besar di Indonesia. keunggulan ini sulit diimitasi oleh strategic group yang beranggotakan Daimler Chrysler dan Land Rover karena membutuhkan waktu dan investasi untuk mengembangkan jaringan pelayanan yang luas di Indonesia.

b. Produsen SUV dengan target segmen konsumen kelas mengenah cenderung mengandalkan harga yang kompetitif disertai fitur kenyamanan dan keselamatan yang memadai. Dalam hal harga terlihat bahwa produk SUV kelas medium jelas berada di bawah SUV prmium. Contoh kasusu adalah manakala KIA Sportage II hendak bersaing dengan SUV menengah Jepang,dengan bermodalkan fitur kenyamanan dan keselamatan yang lebih lengkap dari pesaignnya pada SUV menengah Jepang, pada kenyataannya produk mereka tidak dipersepsikan sekelas dengan SUV menengah Jepang oleh konsumen SUV mengenah di Indonesia.

c. Produsen SUV dengan target segmen konsumen kelas bawah cenderung menggunakan strategi produk yang mengandalkan fungsi dan sisi ekonomis dari sebuah SUV. Pada trategic group yang beranggotakan Daihatsu dan Suzuki menerapkan sedikit inoasi ada teknologi dengan meminimalkan fitur keamanan dan kenyamanan. Hambatan untuk strategic group lain yang ingin masuk ke dalam strategic group ini adalah luasnya jaringan distribusi mereka di Indonesia yang memberikan dukungan jaringan perawatan purna jual yang luas, brand image sebagai kendaraan ekonomis baik dari sisi harga serta biaya operasional dan rendahnya depresiasi harga jual kembali produk-produk mereka. Pesaing di pasar ini datang dari strategic group yang dihuni oleh produsen SUV Korea yaitu KIA dan Hyundai.

\section{Analisis terhadap Strategic Group}

Pengaruh terbesar pada persaingan antar strategic group ada pada market interdependency antar strategic group, yaitu sejauh mana strategi group yang berbeda bersaing untuk pasa yang sama. Jika ada beberapa strategic group bersaing pada segmen pasa yang sama, maka perubahan pilihan strategic dari salah satu strategic group akan sangat berpengaruh pada strategic group yang lain. 


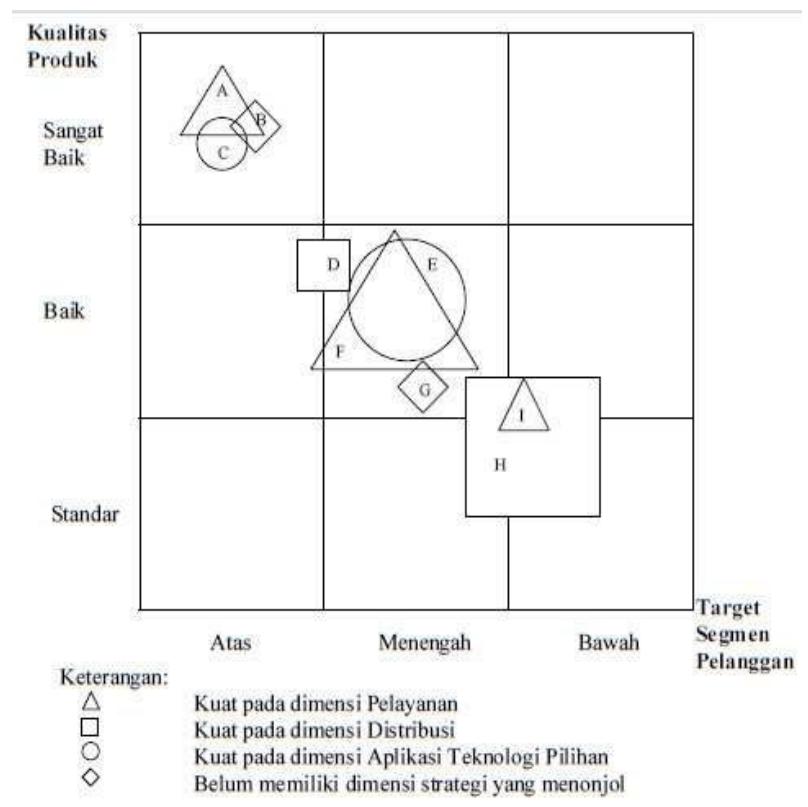

Berikut ini strategic group yang terbentuk di dalam industri kendaraan otomotif:

1. Strategic group A : BMW, Mercedes

2. Strategic group B : Lexus

3. Strategic group C : Land Rover, Daimler Shrysler

4. Strategic group D : Toyota

5. Strategic group E : Honda

6. Strategic group F : Nissan, Mazda, Ford

7. Strategic group G : Chevrolet

8. Strategic group H : Daihatsu, Suzuki

9. Strategic group I : KIA, Hyundai

Strategic group A, B, dan C memiliki market interdepency yang tinggi terhadap satu dengan yang lainnya. Hal ini berarti persaingan antar tiga strategic group ini mempunyai intensitas yang tinggi sehingga jika salah satu anggota dari strategic group ini melakukan perubahan posisi strategic akan sangat berpengaruh pada strategi group yang lain. Kondisi sama juga terjadi pada strategic group E, F, G, dan strategic group H dan I di target segmen pelanggan lain. Bukti besarnya pengaruh market interdependency pada persaingan dalat dilihat dengan sudah tidak produksinya lagi kendaraan SUV oleh strategic group G (Chevrolet) akibat persaingan pada segmen menengah dengan strategic group $\mathrm{E}$ dan $\mathrm{F}$. 


\section{SIMPULAN}

Dimensi Strategik Utama yang Berpengaruh Signifikan pada Segmen- Segmen Pasar Kendaraan SUV

1. Pada group-group yang melayani segmen pelanggan kelas atas, posisi strategik yang lebih baik pada dimensi strategik pelayanan menjadi faktor penting penguasaan mereka terhadap pasar.

2. Pada group-group yang melayani segmen pelanggan kelas menengah, posisi strategik yang lebih baik pada dimensi strategik aplikasi teknologi atau pelayanan menjadi faktor penting penguasaan mereka terhadap pasar.

3. Pada group-group yang melayani segmen pelanggan kelas bawah, posisi strategik yang kuat pada dimensi strategik distribusi (luas cakupan geografis) menjadi faktor penting penguasaan mereka terhadap pasar.

Masukan dari Hasil Analisis bagi Perumusan Strategi Bersaing para Pemain di Industri Kendaraan SUV

1. Para pemain yang memilih untuk melayani segmen pelanggan kelas atas perlu memfokuskan pada perumusan strategi guna memperkuat posisi strategiknya pada dimensi pelayanan.

2. Para pemain yang memilih untuk melayani segmen pelanggan kelas menengah perlu memfokuskan pada perumusan strategi guna memperkuat posisi strategiknya pada dimensi pelayanan dan/atau aplikasi teknologi.

3. Para pemain yang memilih untuk melayani segmen pelanggan kelas bawah perlu memfokuskan pada perumusan strategi guna memperkuat posisi strategiknya pada dimensi keluasan cakupan geografis. 


\section{DAFTAR REFERENSI}

Hunger, J.D, \& Wheelen, T.L. (1996). Manajemen Strategis. Yogyakarta: Penerbit Andi.

Porter, M.E. (1980). Competitive Strategy. New York: The Free Press.

Porter, M.E. (2005). Comptitive Asvantage, Creating and Sustaining Superior Performance. New York: The Free Press.

Caves, R.E., \& Porter M.E. (1977). From Entry Barriers to Mobility Barriers. Quesrterly Journal of Economics, 91,241246.

Thompson, A.A, Strickland, A.J., \% Gamble J.E. (2005). Crafting and Executing Strategy.McGraw-Hill International Edition.

http://www.kompasgramedia.com/business/magazines/autobild www.gaikindo.or.id 